\title{
Avian influenza A(H7N9): information- sharing through government web sites in the Western Pacific Region
}

\author{
Nahoko Harada, ${ }^{a}$ Nyka Alexander ${ }^{a}$ and Babatunde Olowokure ${ }^{a}$ on behalf of the World Health Organization \\ Regional Office for the Western Pacific Event Management Team* \\ Correspondence to Nahoko Harada (e-mail: nahoko.harada.2013@gmail.com)
}

U nder the International Health Regulations (2005), ${ }^{1}$ the Chinese Government reported three human cases of avian influenza A(H7N9) virus on 31 March 2013 to the World Health Organization (WHO). Previous public health events have shown that early detection, rapid response and sharing of information can reduce the impact of emerging and re-emerging diseases. ${ }^{2}$ Risk communication is critical in providing accurate, direct and relevant information as the event unfolds, especially when the disease is of public health importance and/or there is high public anxiety. ${ }^{3,4}$ Communication between government authorities and the public is especially important during these health events, particularly during outbreaks. ${ }^{5}$ The Internet is one important tool used to present information to the public; globally, one in three people have access to the Internet ${ }^{6}$ and Internet search engines, such as Google and Yahoo, have become a frequently used means to obtain information. ${ }^{7,8}$

To assess the web-based risk communication response in the WHO Western Pacific Region for the $A(H 7 N 9)$ event in China, we collated public healthrelated information on $A(H 7 N 9)$ from the countries and areas of the Region for the period 30 April to 2 May 2013. A systematic search of government web sites for each of the 37 countries and areas in the WHO Western Pacific Region was conducted using Google. The search terms used were Ministries of Health, Ministries of Agriculture, Ministries of Foreign Affairs and National Centers for Disease Control. If this strategy did not identify a web site for a country or area, the cabinet or whole-of-government web site was sourced. Once a government web site was identified, and if it had a search facility, the keyword
"H7N9" was used to identify information provided for the $A(H 7 N 9)$ event. If the web site did not have a search facility, press releases or other available information on that site were reviewed for mention of $A(H 7 N 9)$. Pages in languages other than English were assessed by WHO staff from these countries. The information on $A(H 7 N 9)$ from these web sites was categorized according to topics on the WHO A(H7N9) internet pages: general information, epidemiological updates, prevention, advice to travellers, vaccination, clinical guidance and links to WHO web sites. ${ }^{9-12}$ Prevention information was further categorized into four groups: hand hygiene, respiratory hygiene, food preparation and contact with poultry.

We were able to find government web sites for 32 of the 37 countries and areas (four of which were whole-of-government web sites only) using our search strategies. Of these, 13 countries and areas had dedicated and functioning $A(H 7 N 9)$-related pages on 22 government agency web sites: Australia, China, Guam, Hong Kong (China), Japan, Macao (China), Malaysia, Mongolia, New Zealand, Palau, the Philippines, Republic of Korea and Singapore. Six countries and areas had dedicated web sites managed by government agencies: Australia, Hong Kong (China), Japan, Mongolia, New Zealand and two in Singapore.

Seventeen agencies from 12 countries and areas provided information regarding the official notification of the $A(H 7 N 9)$ incident, the actions taken and links to further detailed information on their web sites. Epidemiological updates of reported cases with $A(H 7 N 9)$, along with information such as numbers of cases identified, sex, age or occupation was provided by

\footnotetext{
Division of Health Security and Emergencies, World Health Organization Regional Office for the Western Pacific.

Members of the World Health Organization Regional Office for the Western Pacific Event Management Team: Yuzo Arima, Jang Hwan Bae, Steve Bice,

Joy Rivaca Caminade, Xavier Dufrenot, Emily Jane Fearnley, Alice Ruth Foxwell, Peter Horby, Nori Isoda, Frank Konings, Chin-Kei Lee, Ailan Li,

Michelle McPherson, Zu Rongqiang, Tomoe Shimada.

Submitted: 13 May 2013; Published: 30 May 2013

doi: 10.5365/wpsar.2013.4.2.010
} 
Table 1. Avian influenza A(H7N9) information provided on web sites by countries and areas, Western Pacific Region, 30 April to 2 May 2013

\begin{tabular}{|c|c|c|c|c|c|c|c|c|c|c|c|c|c|c|}
\hline $\begin{array}{l}\text { Countries } \\
\text { and areas }\end{array}$ & $\begin{array}{l}\text { তे } \\
\text { ঠ } \\
\text { D }\end{array}$ & 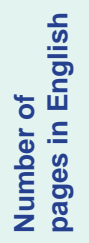 & 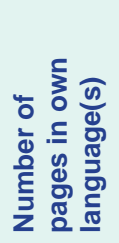 & 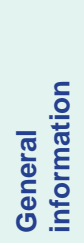 & 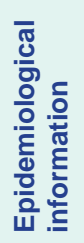 & 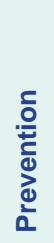 & 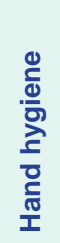 & 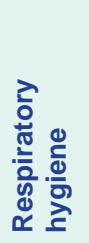 & 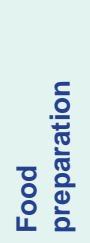 & 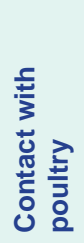 & 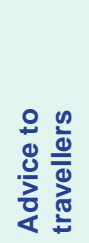 & 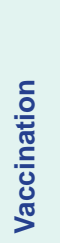 & 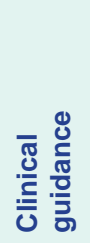 & 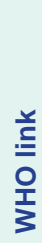 \\
\hline Australia & $\mathrm{MOH}$ & 12 & & $\checkmark$ & $\checkmark$ & $\checkmark$ & $\checkmark$ & & $\checkmark$ & & $\checkmark$ & & $\checkmark$ & $\checkmark$ \\
\hline \multirow[t]{2}{*}{ China } & $\mathrm{MOH}$ & - & 217 & $\checkmark$ & $\checkmark$ & $\checkmark$ & $\checkmark$ & $\checkmark$ & $\checkmark$ & & & $\checkmark$ & & \\
\hline & MOA & 3 & & & & & & & & & & & & \\
\hline Guam & $\mathrm{MOH}$ & 2 & & $\checkmark$ & & $\checkmark$ & $\checkmark$ & $\checkmark$ & $\checkmark$ & & & & & \\
\hline \multirow{2}{*}{$\begin{array}{l}\text { Hong Kong } \\
\text { (China) }\end{array}$} & $\mathrm{MOH}$ & 128 & & $\checkmark$ & $\checkmark$ & $\checkmark$ & $\checkmark$ & $\checkmark$ & & $\checkmark$ & $\checkmark$ & & $\checkmark$ & $\checkmark$ \\
\hline & MOA & 1 & & $\checkmark$ & & & & & & & & & & \\
\hline \multirow[t]{2}{*}{ Japan } & $\mathrm{MOH}$ & 1 & 38 & $\checkmark$ & & $\checkmark$ & $\checkmark$ & $\checkmark$ & $\checkmark$ & $\checkmark$ & $\checkmark$ & $\checkmark$ & & $\checkmark$ \\
\hline & MOA & - & 16 & & & & & & & & & & & \\
\hline \multirow{2}{*}{$\begin{array}{l}\text { Macao } \\
\text { (China) }\end{array}$} & $\mathrm{MOH}$ & - & 10 & $\checkmark$ & & $\checkmark$ & $\checkmark$ & $\checkmark$ & $\checkmark$ & & $\checkmark$ & & $\checkmark$ & \\
\hline & MOA & - & 63 & $\checkmark$ & & $\checkmark$ & $\checkmark$ & $\checkmark$ & $\checkmark$ & & $\checkmark$ & & $\checkmark$ & \\
\hline \multirow[t]{2}{*}{ Malaysia } & $\mathrm{MOH}$ & 33 & 13 & $\checkmark$ & $\checkmark$ & $\checkmark$ & $\checkmark$ & & & & & $\checkmark$ & & \\
\hline & MOFA & 61 & 1 & $\checkmark$ & $\checkmark$ & & & & & & & & & \\
\hline \multirow[t]{2}{*}{ Mongolia } & $\mathrm{MOH}$ & - & 7 & $\checkmark$ & $\checkmark$ & $\checkmark$ & $\checkmark$ & & $\checkmark$ & $\checkmark$ & $\checkmark$ & & $\checkmark$ & $\checkmark$ \\
\hline & MOFA & - & 1 & $\checkmark$ & $\checkmark$ & & . & & & & & & & \\
\hline New Zealand & $\mathrm{MOH}$ & 2 & & $\checkmark$ & $\checkmark$ & $\checkmark$ & $\checkmark$ & & $\checkmark$ & & $\checkmark$ & & & $\checkmark$ \\
\hline Palau & $\mathrm{MOH}$ & 3 & & & & & & & & & & & & $\checkmark$ \\
\hline $\begin{array}{l}\text { The } \\
\text { Philippines }\end{array}$ & $\mathrm{MOH}$ & 2 & & $\checkmark$ & & & & & & & & & $\checkmark$ & \\
\hline $\begin{array}{l}\text { Republic of } \\
\text { Korea }\end{array}$ & $\mathrm{MOH}$ & - & 1 & $\checkmark$ & & & & & & & & & & \\
\hline \multirow[t]{2}{*}{ Singapore } & $\mathrm{MOH}$ & 2 & & $\checkmark$ & $\checkmark$ & $\checkmark$ & $\checkmark$ & $\checkmark$ & & & $\checkmark$ & & & \\
\hline & MOA & 1 & & $\checkmark$ & $\checkmark$ & $\checkmark$ & & $\checkmark$ & $\checkmark$ & & & & & \\
\hline Total & & 251 & 367 & 17 & 10 & 12 & 11 & 8 & 9 & 3 & 8 & 3 & 6 & 6 \\
\hline
\end{tabular}

MOA - Ministry of Agriculture; MOFA - Ministry of Foreign Affairs; MOH - Ministry of Health.

10 agencies from seven countries and areas (Table 1). The Singapore Government also uploaded case reports on their Consular web site aimed at foreign residents and incoming travellers.

Twelve agencies from 10 countries and areas provided information on prevention for $A(H 7 N 9)$. The most common prevention recommendations were for frequent hand washing (with two agencies also specifying that the concentration of alcohol in the hand cleanser should be more than $60 \%$ ), respiratory hygiene such as covering the mouth when sneezing or coughing and food preparation recommendations including avoidance of raw or undercooked meat and eggs (Table 1). None of the web sites mentioned the importance of separating uncooked food from cooked food and kitchen utensils.
Eight agencies from seven countries and areas advised travellers returning from affected areas to monitor their health and seek medical attention if certain symptoms developed; a smaller number suggested that travellers avoid live/wet bird markets in affected countries. Two countries and areas referred to WHO advice that screening at points of entry or travel restrictions are not necessary (Table 1 ).

Clinical guidance information specific to $A(H 7 N 9)$ was provided by six agencies from five countries and areas (Table 1) that included advice on case management for general practitioners and clinicians, the criteria set for requesting laboratory tests from suspected cases, standard laboratory test procedures and contact information of local and national test centres. 
Links to the WHO $A(H 7 N 9)$ resource web sites, including pages on clinical management, ${ }^{13}$ technical guidance specific to virology and laboratory, ${ }^{13}$ "Frequently Asked Questions," 9 "Background and summary of human infection with influenza A(H7N9) virus," 11 "Global Alert and Response" 16 and its subsection "Disease Outbreak News"16 were provied on the web sites of six countries and areas.

Although we have provided a snapshot of the information being disseminated though the Internet for the $A(H 7 N 9)$ response, there are some limitations to our analysis. First, the search method used was not exhaustive, thus some relevant web sites and pages may have been missed. Also, the web sites that were accessed may have been updated since our assessment. To obtain updated information provided by these agencies, direct access to their web sites is strongly recommended.

The Internet is only one mechanism for risk communication, and not all people have equal access to the Internet. Some countries and areas may not have the capacity to build and maintain a web site or upload information in a timely manner for emerging events. Others may not want to duplicate efforts and instead rely on existing web sites. Nevertheless, the internet has become a commonly-used way of sharing information with the public that can be disseminated worldwide. The Internet is an inexpensive risk communication tool compared to traditional means such as printing pamphlets or posters or radio and television.

Our assessment, one month after the first cases were reported, revealed that 13 of 37 WHO Western Pacific Region countries and areas were providing information to the public through their government web sites, consisting mostly of information on the epidemiology of the event in China, prevention methods for avian influenza, clinical management and links to WHO web sites. We recommend that the countries that have not yet done so consider following the example of others in the Region in providing information about $\mathrm{A}(\mathrm{H} 7 \mathrm{~N} 9)$ (or links to other web sites with this information) on their web sites.

\section{Conflicts of interest}

None declared

\section{Funding}

None.

\section{References:}

1. The International Health Regulations (2005). Geneva, World Health Organization, 2007 (http://www.who.int/ihr/9789241596664/ en/index.html, accessed 9 May 2013).

2. Jardine $\mathrm{C}$ et al. Risk management frameworks for human health and environmental risks. Journal of Toxicology and Environmental Health. Part B, Critical Reviews, 2003, 6:569-720. pmid:14698953

3. Glik DC. Risk communication for public health emergencies. Annual Review of Public Health, 2007, 28:33-54 doi:10.1146/ annurev.publhealth.28.021406.144123 pmid:17222081

4. Asia Pacific Strategy for Emerging Diseases (2010). Manila, World Health Organization Regional Office for the Western Pacific, 2011 (http://www.wpro.who.int/emerging_diseases/documents/ ASPED 2010/en/index.html, accessed 3 May 2013).

5. Quinn SC et al. Exploring communication, trust in government, and vaccination intention later in the $2009 \mathrm{H} 1 \mathrm{~N} 1$ pandemic: results of a national survey. Biosecurity and bioterrorism: biodefense strategy, practice, and science, 2013, Apr 25. pmid:23617721

6. Measuring the information society: 2012 Executive Summary 2012. Geneva, International Telecommunication Union, 2012 (http://www.itu.int/ITU-D/ict/publications/idi/material/2012/ MIS2012-ExecSum-E.pdf, accessed 3 May 2013).

7. Corley $C D$ et al. Using Web and social media for influenza surveillance. Advances in Experimental Medicine and Biology, 2010, 680:559-564. doi:10.1007/978-1-4419-5913-3 61 pmid:20865540

8. Ginsberg J et al. Detecting influenza epidemics using search engine query data. Nature, 2009, 457:1012-1014. doi:10.1038/ nature07634 pmid:19020500

9. Frequently Asked Questions on human infection caused by the avian influenza $A(H 7 N 9)$ virus, China. Geneva, World Health Organization, 2013 (http://www.who.int/influenza/human animal_interface/faq_H7N9/en/, accessed 3 May 2013).

10. Human infection with avian influenza $A(H 7 N 9)$ virus in China update 2013. Geneva, World Health Organization, 2013 (http:// www.who.int/csr/don/2013_04_22/en/index.html, accessed 3 May 2013).

11. Background and summary of human infection with influenza A(H7N9) virus. Geneva, World Health Organization, 2013 (http:// www.who.int/influenza/human_animal_interface/latest_update h7n9/en/index.html, accessed 3 May 2013).

12. International travel and health: avian influenza. Geneva, World Health Organization, 2013 (http://www.who.int/ith/diseases/ avianinfluenza/en/, accessed 3 May 2013).

13. Clinical management of human infection with avian influenza $A(H 5 N 1)$ virus. Geneva, World Health Organization, 2013 (http://www.who.int/influenza/resources/documents/ ClinicalManagement07.pdf, accessed 3 May 2013).

14. Real-time RT-PCR protocol for the detection of avian influenza A(H7N9) virus. Geneva, World Health Organization, 2013 (http:// www.who.int/influenza/gisrs_laboratory/cnic_realtime_rt_pcr_ protocol_a_h7n9.pdf, accessed 3 May 2013).

15. Global Alert and Response. Geneva, World Health Organization, 2013 (http://www.who.int/csr/en/, accessed 9 May 2013).

16. Disease Outbreak News. Geneva, World Health Organization, 2013 (http://www.who.int/csr/don/en/, accessed 9 May 2013). 